\title{
ECONOMIC OPPORTUNITIES OF RADIO-FREQUENCY IDENTIFICATION TECHNOLOGY USAGE IN POWER DISTRIBUTION SECTOR
}

\author{
WOJCIECH DROŻDŻ, ${ }^{1}$ RENE KUCZKOWSKI ${ }^{2}$ \\ ${ }^{1}$ University of Szczecin, Faculty of Management and Economics of Services, POLAND \\ e-mail: wojciech.drozdz@wzieu.pl \\ ${ }^{2}$ Enea Operator sp. z o.o., POLAND \\ e-mail: rene.kuczkowski@enea.pl
}

RECEIVED
ACCEPTED
JEL
CLASSIFICATION

KEYWORDS

ABSTRACT
6 November 2018

3 December 2018

Q14, Q40, R41

RFID, SWOT, radio frequency identification, electricity market, energy distribution

The aim of the article was to present and analyze possible usage of Radio-Frequency Identification Technology in Polish Distribution System Operator company. Presentation of technology was focused on technology opportunities, principle of operation, other companies implementation and possibilities of usage in Polish electricity distribution market. Also some experience from pilot project were presented. Gathered experience led to choice of carrying out the SWOT analysis to identify possible threats and opportunities from implementing technology for the enterprise. Results showed, that the company should take further steps in Radio-Frequency technology implementation. Nevertheless, in order to confirm those analysis, more data should be gathered and once more analyzed.

\section{Introduction}

In the era of digitization and globalization, information gains in importance. Its possession allows for more efficient management or gaining a competitive advantage in the realities of business. The power sector is also experiencing similar transformations. Nowadays, when Distribution System Operators (DSO) are implementing smart solutions or the automation of the network, the possession of information becomes an indispensable element 
of their operational activities. There are many solutions in the world that allow effective identification of selected objects. Presently the most popular form is the use of bar codes. A significant common disadvantage of the above solutions is undoubtedly its lability. Exposing them to external atmospheric conditions usually results in fading, soiling or mechanical damage effectively prevents later identification of the object. It generates additional costs, which should be optimized precisely by applying more rugged solutions.

On the horizon, radio frequency identification technology, also known as RFID, appears. Operating with the use of radio waves, it enables remote identification and localization of a given object from a distance of up to 7 meters (Srikant, Mahapatra, 2010, p. 324). The microchips used have a much larger memory capacity than graphical solutions (McFalrane, Sheffi, 2003, p. 9). Complementary, programming capabilities allow effective protection of the identifier against unauthorized reading or interference in the data. The advantage is also increased resistance to external factors and the possibility of current editing of saved information. This technology, so far used in the area of a logistics and transport sector, is gradually gaining other fields that require inventory or tracking of specific items (Hinkka, Holmstrom, Framling, 2012, pp. 199-200).

Currently RFID technology is mostly used in warehouse and logistics sector. One of the most successful implementation was held by French sporting goods retailer - Decathlon. Project started in 2010 and by 2015 almost 800 stores were using RFID technology. Thanks to this technology, the company noted the sales improved by $11 \%$ and the rate of commodity losses were reduced by $9 \%$ (Violino, 2016).

The development of remote identification is a great opportunity for the Polish power industry. A significant part of network assets are located in areas that are inaccessible due to environmental reasons, where there are for example forests or wetlands. The issue of DSO operational activities is not without significance. If it is necessary to carry out the inventory, often the power grid operation makes it impossible to exclude individual objects. In this case, remote identification or modification is a desired improvement that will allow to optimize works on the grid. The use of information plates and RFID tags on grid objects at the same time will allow for its easy reading and identification in case of damage or theft of the plate. Finally, the relatively small dimensions of the tags give the possibility of hiding them in a given structure.

Since 2015, Polish DSO's are testing RFID technology for its own purposes. At present time some pilot projects are carried out to check their technical and economical profitability. First results show that, in case of technical adaptation, this technology is an innovation for the electricity distribution sector. Due to the above, there are currently no economic models justifying the return on the implementation of this type of investment. Companies believe that first major roll-outs can result in specific figures, that will state profitability of RFID implementation. That made the most reasonable to determine the benefits of implementing RFID in the company by using SWOT analysis. It will allow to categorize possible threats and opportunities for the company thanks to rolling-out Radio Frequency Identification technology (Obłój, 2007, pp. 106-107).

The primary purpose of the article was to identify and analyze possible strategic advantages of introducing RFID technology in the power sector company by using SWOT analysis.

\section{Basic aspects of RFID System}

The basic RFID system consists of the following elements (Finkenzeller, 2010, p. 6):

- transponder (tag), which is attached to the object being subject to identification,

- a reader that, depending on the technology, can be used to read, read and write data to the transponder, 
- software thanks to which the system identifies a given object in the data cloud and provides its data for further processing,

SOFTWARE

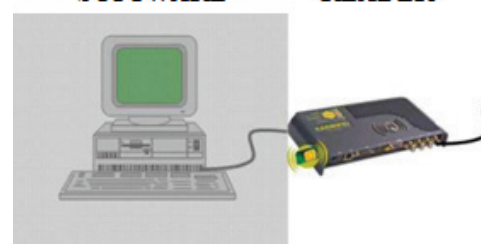

Figure 1. The scheme of components of the RFID system

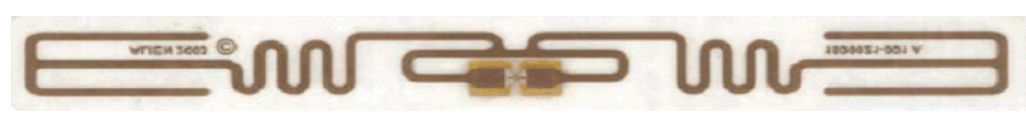

Figure 2. The general scheme of the RFID tag

Source: internet.

The reader usually consists of a radio communication module, a control system and an antenna that makes it possible to stimulate a radio signal for the needs of the transponder. In addition, it is often equipped with a communication interface (RS 232, RS 485, Bluetooth, USB, etc.), thanks to which the read data can be transferred directly to the software. The general structure of the tag consists of three parts. The first of these is the antenna, which is responsible for wireless communication as a result of excitation by the reader. The second one is a microchip that has encoded control data as well as a memory storing the encoded data. In addition, depending on the technology used, the tag may be equipped with an additional power supply to maintain tag activity (Rutkowski, 2003, p. 3).

\section{Curpent tests held in DSO company}

Currently, Polish DSOs are testing solutions related to RFID in their own operations. The following results present a pilot installation of this solution together with the identification of the company's needs and the learning of a new technology in this sector. The scope of the pilot included the installation and operational test of RFID technology for the purpose of recording power utilities. The aspects of assembly were examined, including such issues as tag distinction from other companies transponders, the place of assembly on each of the objects, the way of preparing the surface before assembly, necessary tools to work with the RFID system, as well as tests and inventory after correctly implemented records. The tests covered three different areas of DSO with about 100 network objects that were marked and recorded in accordance with the prepared technical assumptions. 


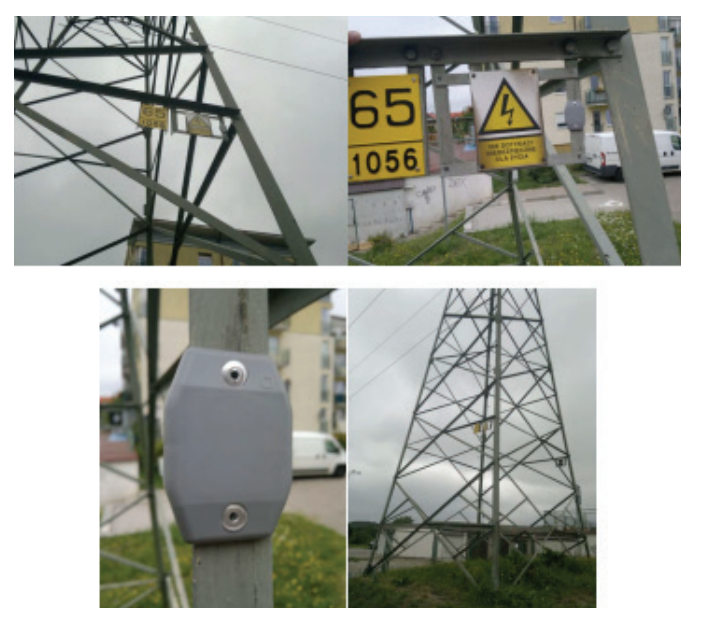

Figure 3. RFID tag installed on HV pole

Source: own work.

After the pilot was completed, several important technical conclusions were identified:

a) there is no impact on the reading performance due to device operation;

b) there is some influence of atmospheric conditions on the reading efficiency;

c) all of the RFID tag have been read successfully.

The experience gathered in the technical tests of technology formed the basis for the identification and development of economic assumptions for the implementation of RFID technology in the entire company.

\section{Economic analysis of implementing RFID in DSO company}

Due to the novelty of the solution, which is the radio identification of devices, it is necessary to analyze the possibilities related to its implementation in the company. It is justified in this case to use the SWOT analysis model to determine strategic directions and recommendations for issues and problems (Gierszewska, Romanowska, 2017, pp. 189-191) related to the implementation of RFID technology. Key SWOT factors are presented below (Table 1).

Tahle 1. SWOT analysis of implementing RFID technology in DSO's company operation

\begin{tabular}{|c|c|}
\hline Strengths & Weaknesses \\
\hline 1. High quality of collected data. & 1. Low company experience with RFID technology. \\
\hline 2. Resistance to most weather conditions. & 2. High implementation costs due to the large number of power \\
\hline 3. Falling costs of system components. & devices. \\
\hline 4. Tags are maintenance-free. & 3. Water can interrupt tag operation. \\
\hline 5. Relatively simple assignment to other systems & $\begin{array}{l}\text { 4. Complexity of implementation due to internal processes. } \\
\text { 5. Possible problems with data quality in current databases }\end{array}$ \\
\hline Opportunities & Threats \\
\hline \multicolumn{2}{|c|}{ 1. Better quality of assets information can affect faster operations on the grid. 1. Society privacy concerns. } \\
\hline $\begin{array}{l}\text { 2. Using RFID with external contractors can facilitate the management } \\
\text { of materials needed for the investments. }\end{array}$ & $\begin{array}{l}\text { 2. Benefits can be insufficient compared to bar codes. } \\
\text { 3. Due to DSO's large investment needs, the RFID can }\end{array}$ \\
\hline 3. On demand information can improve supplies management. & be a low-priority. \\
\hline 4. Unambiguous device marking can improve grid work safety & 4. Some gathered data can be aim of cyber attacks \\
\hline
\end{tabular}

Source: drawn by the author based on company data. 
Relations how strengths allows to use opportunities presents Table 2 .

Table 2. S-O analysis

\begin{tabular}{|c|c|c|c|c|c|c|c|}
\hline Strengths|Opportunities & 01 & 02 & 03 & 04 & Weight (\%) & $\begin{array}{c}\text { Sum } \\
\text { of connections }\end{array}$ & $\begin{array}{l}\text { Weighted sum } \\
\text { of connections }\end{array}$ \\
\hline S1 & 1 & 0 & 1 & 1 & 40 & 3 & 1.2 \\
\hline S2 & 1 & 0 & 0 & 1 & 20 & 2 & 0.4 \\
\hline S3 & 0 & 1 & 1 & 0 & 10 & 2 & 0.2 \\
\hline S4 & 0 & 1 & 1 & 1 & 10 & 3 & 0.3 \\
\hline S5 & 1 & 0 & 1 & 0 & 20 & 2 & 0.4 \\
\hline Weight (\%) & 40 & 10 & 25 & 25 & & & \\
\hline Sum of connections & 3 & 2 & 4 & 3 & & 24 & \\
\hline Weighted sum of connections & 1.20 & 0.20 & 1.00 & 0.75 & & & 5.65 \\
\hline
\end{tabular}

Source: drawn by the author based on company data.

Relations how strengths allows to restrain threats presents Table 3.

Table 3. S-T analysis

\begin{tabular}{cccccccc}
\hline StrengthsIThreats & T1 & T2 & T3 & T4 & Weight (\%) & $\begin{array}{c}\text { Sum } \\
\text { of connections }\end{array}$ & $\begin{array}{c}\text { Weighted sum } \\
\text { of connections }\end{array}$ \\
\hline S1 & 0 & 1 & 1 & 0 & 40 & 2 & 0.8 \\
S2 & 0 & 1 & 0 & 0 & 20 & 1 & 0.2 \\
S3 & 0 & 1 & 1 & 0 & 10 & 2 & 0.2 \\
S4 & 0 & 1 & 1 & 0 & 10 & 2 & 0.2 \\
S5 & 0 & 0 & 1 & 1 & 20 & 18 & \\
\hline Weight (\%) & 10 & 40 & 40 & 10 & & & \\
\hline Sum of connections & 0 & 4 & 4 & 1 & & & \\
\hline Weighted sum of connections & - & 1.60 & 1.60 & 0.10 & & & \\
\hline
\end{tabular}

Source: drawn by the author based on company data.

Relations how weaknesses limits opportunities presents Table 4.

Table 4. W-O analysis

\begin{tabular}{|c|c|c|c|c|c|c|c|}
\hline Weaknesses|Opportunities & 01 & 02 & 03 & 04 & Weight (\%) & $\begin{array}{c}\text { Sum } \\
\text { of connections }\end{array}$ & $\begin{array}{l}\text { Weighted sum } \\
\text { of connections }\end{array}$ \\
\hline W1 & 1 & 0 & 0 & 1 & 10 & 2 & 0.2 \\
\hline W2 & 0 & 1 & 1 & 0 & 20 & 2 & 0.4 \\
\hline W3 & 0 & 0 & 0 & 1 & 10 & 1 & 0.1 \\
\hline W4 & 1 & 0 & 0 & 0 & 30 & 1 & 0.3 \\
\hline W5 & 1 & 0 & 0 & 1 & 30 & 2 & 0.6 \\
\hline Weight (\%) & 40 & 10 & 25 & 25 & & & \\
\hline Sum of connections & 3 & 1 & 1 & 3 & & 16 & \\
\hline Weighted sum of connections & 1.20 & 0.10 & 0.25 & 0.75 & & & 3.90 \\
\hline
\end{tabular}

Source: drawn by the author based on company data. 
Relations how weaknesses intensifies threads presents Table 5.

Table 5. W-T analysis

\begin{tabular}{cccccccc}
\hline WeaknessesiThreats & T1 & T2 & T3 & T4 & Weight (\%) & $\begin{array}{c}\text { Sum } \\
\text { of connections }\end{array}$ & $\begin{array}{c}\text { Weighted sum } \\
\text { of connections }\end{array}$ \\
\hline W1 & 1 & 1 & 1 & 1 & 10 & 4 & 0.4 \\
W2 & 0 & 1 & 1 & 0 & 20 & 2 & 0.4 \\
W3 & 0 & 1 & 0 & 0 & 10 & 1 & 0.1 \\
W4 & 1 & 0 & 0 & 1 & 30 & 3 & 0.6 \\
W5 & 0 & 1 & 0 & 1 & 30 & & 22 \\
\hline Weight (\%) & 10 & 40 & 40 & 10 & & & \\
\hline Sum of connections & 2 & 4 & 2 & 3 & & & \\
\hline Weighted sum of connections & 0.20 & 1.60 & 0.80 & 0.30 & & & \\
\hline
\end{tabular}

Source: drawn by the author based on company data.

Overall SWOT analysis and strategy selection presents Table 6.

Tahle 6. Overall SWOT analysis and strategy selection

\begin{tabular}{lcc} 
& Opportunities (O) & Threats (T) \\
\cline { 2 - 3 } & Aggressive strategy & Conservative strategy \\
Sum of connections & 24 & Sum of connections \\
& Weighted sum of connections & 18 \\
\hline Competitive strategy & Weighted sum of connections \\
& Sum of connections & 5.10 \\
\hline Weaknesses $(W)$ & 16 & Defensive strategy \\
& Weighted sum of connections & Sum of connections \\
& 3.90 & 22 \\
\hline
\end{tabular}

Source: drawn by the author based on company data.

From the above analysis it can be concluded that the aggressive strategy is the most justified, which will make the most of the strengths and opportunities. This means that the implementation of the project should primarily allow the use of opportunities, which are the benefits of the implementation of unambiguous marking of power devices and the ability to optimize the supply chain in combination with warehouse management of the Distribution System Operator.

Nevertheless, a similar result for a defensive strategy may indicate the need to conduct an in-depth analysis of the assumptions and scope of the project. This may result indirectly from insufficient knowledge about the technology itself as well as knowledge of the market environment related to the use of RFID technology. Before the decision of RFID roll-out, the project team should consult with internal and external stakeholders for the purpose of redesigning the assumptions and final effects resulting from the project implementation. 


\section{Conclusions}

Present-day puts Distribution Network Operators in a new reality. The main operational activity of the DSO remained unchanged - provide the end user with electricity. However, today's DSO task is not just distribution itself. One of the actions that must be taken into account is the strict record of their assets. This is the challenge, that could be restrained by RFID systems. Due to the earlier indicated benefits, a pilot system check was carried out under operating conditions. Taking into account the success of the activities carried out and SWOT analysis the DSO will most likely decide on further steps in this direction. However, due to the relatively low knowledge in the use of this technology, company should take actions in order to specify the scope of the project, its economic efficiency and impact on the operational activities.

\section{References}

Finkenzeller, K.(2010). RFID Handbook. United Kingdom: John Wiley and Sons Ltd.

Gierszewska, G., Romanowska, M. (2017). Analiza strategiczna przedsiębiorstwa. Warszawa: PWE.

Hinkka, V., Holmstrom, J., Framling K. (2012). RFID tracking in the book supply chain: The transition from postponed to speculative tagging. International Journal of Logistics Research and Applications, 15 (3), 199-214.

McFalrane, D., Sheffi, Y. (2003). The Impact of Automatic Identification on Supply Chain Operations. The International Journal of Logistics Management, 14 (1), 1-17.

Obłój, K. (2014). Strategia organizacji. Warszawa: PWE.

Rutkowski, K. (2003). Technologia RFID w zarządzaniu łańcuchem dostaw. Gospodarka Materiałowa i Logistyka, 12, 2-6.

Srikant, S., Mahapatra, R.P. (2010). Read Range of UHF Passive RFID. International Journal of Computer Theory and Engineering, 2 (3), 323-325.

Violino, B. (2016). Decathlon Scores a Big Win With RFID. RFID Journal. Retrieved from: https://www.rfidjournal.com/purchase-acces s?type=Article\&id=14621\&r=\%2Farticles $\% 2 F v i e w \% 3 F 14621$.

Cite this article aS: Drożdż, W., Kuczkowski, R. (2018). Economic opportunities of radio-frequency identification technology usage in power distribution sector. European Journal of Service Management, 4 (28/1), 117-123. DOI: 10.18276/ejsm.2018.28/1-15. 